\title{
Studi Anak Stunting dan Normal Berdasarkan Pola Asuh Makan serta Asupan Zat Gizi di Daerah Program Penanggulangan Stunting Kabupaten Pasaman, Pasaman Barat
}

\author{
Masrul
}

\begin{abstract}
Abstrak
Anak di bawah lima tahun di seluruh dunia seperempatnya mengalami stunting. Stunting adalah dampak dari kondisi sistemik kekurangan gizi kronik. Indonesia merupakan negara dengan peringkat kelima yang mengalami stunting terbanyak di dunia yaitu sebanyak 7,6 juta (37\%) anak mengalami stunting. Untuk itu, sejak tahun 2017 pemerintah berusaha menurunkan angka stunting di 100 kabupaten/ kota di Indonesia, khususnya Kabupaten Pasaman dan Pasaman Barat dengan angka stunting nasional di atas 46,1\%. Penyebab stunting yaitu rendahnya angka sosial ekonomi, pola asuh makan, intake zat gizi, kebijakan negara, dan sebagainya. Tujuan penelitian ini adalah untuk mengetahui karakteristik anak stunting dan anak normal berdasarkan pola asuh makan dan intake zat gizi. Data diperoleh dengan mewawancarai ibu responden dan melakukan dietary assessment $1 \times 24$ jam, kemudian data dianalisis menggunakan uji chi-square dengan $p<0,05$ signigfikansi. Responden terdiri 94 anak stunting dan 91 anak normal di Kabupaten Pasaman dan Kabupaten Pasaman Barat. Diketahui bahwa dalam penelitian ini, kejadian stunting berhubungan dengan panjang lahir anak dan bentuk keluarga, namun tidak berhubungan terhadap pola asuh makan dan intake zat gizi.
\end{abstract}

Kata kunci: stunting, pola asuh makan, intake zat gizi

\section{Abstract}

A quarter of children under five in the entire world are getting stunting. Stunting is the effect of a systemic condition of chronic malnutrition. Indonesia is the country with a fifth ranking of the most stunting in the world, namely 7.6 million $(37 \%)$ children who experience stunting. For this reason, since 2017 the government has been trying to reduce stunting rates in 100 regencies in Indonesia, especially Pasaman and West Pasaman Regency with national stunting rates above $46.1 \%$. The causes of stunting are low socioeconomic numbers, diet, nutritional intake, state policy, and so on. The objective of this study was to know the characteristics of stunting children and normal children based on feeding patterns and nutrient intake. Data were obtained by interviewing the respondent's mother and evaluating the $1 \times 24$ hours diet, then the data were analyzed using the chi-square test with $p<0.05$ significance. Respondents consisted of 94 stunting children and 91 normal children in Pasaman Regency and West Pasaman Regency. It was known that in this study, stunting events were related to the birth length of the child and family form, but were not related to parenting style and nutrient intake.

Keywords: stunting, feeding pattern, nutrient intake

Affiliasi penulis: Bagian IImu Gizi, Fakultas Kedokteran Universitas Andalas

Korespondensi : Jl. Perintis Kemerdekaan No. 94 Padang, Email: masrul@med.unand.ac.id Hp: +62 81363152961

\section{PENDAHULUAN}

Anak di bawah lima tahun di seluruh dunia seperempatnya mengalami stunting. Stunting adalah dampak dari kondisi sistemik kekurangan gizi kronik. Stunting anak dapat berkembang 
selama dua tahun pertama kehidupan dan sebagian besar disebabkan oleh kekurangan nutrisi, pengasuhan dan kesakitan ${ }^{1}$. Diperkirakan terdapat 159 juta anak stunting tinggal di negara berpenghasilan rendah pada tahun 2014. 2,3 Data

Stunting tidak terlepas dari berbagai faktor yang ditentukan oleh penentu yang tersusun berlapis (langsung, tidak langsung, dan dasar). Dalam penelitian ini difokuskan pada faktor penentu yaitu pola asuh makan, intake zat gizi, berat lahir anak dan pemberian ASI ibu.

Efek jangka panjang stunting yaitu penurunan tingkat kelangsungan hidup, gangguan perkembangan kognitif dan motorik, penurunan produktivitas ekonomi, dan kesempatan yang lebih tinggi untuk hidup dalam kemiskinan di masa dewasa. ${ }^{1,4}$.

Tujuan penelitian ini adalah untuk mengetahui karekteristik anak stunting berdarakan pola asuh makan dan intake zat gizi pada lokus Kabupaten Pasaman Barat dan Kabupaten Pasaman dari 100 Kabupaten/Kota yang diintervensi stunting di Indonesia. Penelitian ini merupakan salah satu bagian dari penelitian besar melalui kerjasama antara Direktorat Gizi Masyarakat Kemeterian Kesehatan RI dan Fakultas Kedokteran Universitas Andalas pada tahun 2018 mengenai stunting Kab. Pasaman dan Pasaman Barat, Prov. Sumatera Barat dengan nomor kontrak KN.01.01/2/1302/2018 dan 2655/UN.16.2/TU/ 2018.

\section{METODE}

Design sampel dari penelitian ini yaitu cross sectional study komparatif. Populasi target dalam penelitian ini adalah semua anak usia 0-3 tahun di wilayah Kabupaten Pasaman dan Pasaman dan Pasaman Barat. Subyek dalam penelitian ini adalah anak stunting dan normal yang dipilih dengan perbandingan anak stunting dan normal 1:1. Stunting adalah balita usia -3 tahun dengan indeks z-score TB/U $\leq-2 S D$, sedangkan normal adalah balita usia 0-3 tahun dengan indeks zscore TB/U -2SD s/d +2SD. Responden dalam penelitian ini adalah Ibu balita yang terpilih menjadi subyek penelitian. Kriteria inklusi dalam penelitian ini adalah balita berusia 0-3 tahun yang tinggal dan menetap di Kabupaten Pasaman dan Pasaman Barat, tidak sakit maupun cacat dan tinggal bersama kedua orang tua, serta memiliki Kartu Menuju Sehat (KMS). Jumlah subyek pada masing-masing kelompok sebanyak 94 anak stunting dan 91 anak normal.

Variabel terikat dalam penelitian ini adalah stunting, sedangkan variabel bebas adalah panjang badan lahir, status ekonomi keluarga, tingkat pendidikan dan tinggi badan orang tua, pola asuh makanan dan angka kecukupan gizi makro dan mikro (intake zat gizi).

Pengambilan data dilakukan oleh lima orang lulusan D3 Gizi yang telah terlatih dalam Riskesdas 2018. Data yang dikumpulkan adalah data intake makan 1 × 24 jam dengan food recall, menggunakan kuesioner untuk data karakteristik anak, keluarga, dan pola asuh makan. Data yang diperoleh kemudian dianalisis menggunakan uji Chi-square sehingga terlihat hubungan antarvariabel penelitian.

HASIL

\section{Karakteristik Responden}

Karakteristik responden dalam penelitian ini diketahui lebih dari separuh responden (50.27\%) berjenis kelamin laki-laki dan kurang dari separoh responden $(49.73 \%)$ berjenis kelamin perempuan. Karakteristik responden lainnya dapat dilihat sebagai berikut. 
Tabel 1.1. Karakteristik responden

\begin{tabular}{|c|c|c|c|}
\hline \multirow[b]{2}{*}{ Variabel } & \multicolumn{2}{|c|}{ Status Gizi } & \multirow[b]{2}{*}{$p$} \\
\hline & $\begin{array}{l}\text { Stunting } \\
(n=94)\end{array}$ & $\begin{array}{l}\text { Normal } \\
(n=91)\end{array}$ & \\
\hline $\begin{array}{l}\text { Karakteristik } \\
\text { - anak }\end{array}$ & & & \\
\hline $\begin{array}{l}\text { Umur anak } \\
\text { (bulan), mean } \pm S D\end{array}$ & $23.97 \pm 6.74$ & $24.44 \pm 6.95$ & 0.640 \\
\hline $\begin{array}{l}\text { Berat badan lahir } \\
\text { bayi (gram), } \\
\text { mean } \pm \text { SD }\end{array}$ & $\begin{array}{c}3284.04 \pm 480 \\
.65\end{array}$ & $\begin{array}{c}3210.88 \pm 478 \\
.83\end{array}$ & 0.301 \\
\hline $\begin{array}{l}\text { Panjang badan } \\
\begin{array}{l}\text { bayi } \\
\text { mean } \pm S D\end{array}\end{array}$ & $41.54 \pm 16.80$ & $46.93 \pm 8.85$ & $0.007^{*}$ \\
\hline $\begin{array}{l}\text { Anak ke, } \\
\text { mean } \pm S D \\
\text { - Keluarga }\end{array}$ & $2.56 \pm 1.54$ & $2.60 \pm 1.44$ & 0.854 \\
\hline $\begin{array}{l}\text { Pendidikan kepala } \\
\text { keluarga, } f(\%)\end{array}$ & & & \\
\hline $\begin{array}{l}\text { Tidak pernah } \\
\text { sekolah }\end{array}$ & $15(16.0)$ & $5(5.5)$ & $0.003^{*}$ \\
\hline Tidak tamat SD & $19(20.2)$ & $6(6.6)$ & \\
\hline Tamat SD & $28(29.8)$ & $31(34.1)$ & \\
\hline Tamat SMP & $13(13.8)$ & $18(19.8)$ & \\
\hline Tamat SMA & $16(17.0)$ & $30(33.0)$ & \\
\hline $\begin{array}{l}\text { Tamat Diploma/ } \\
\text { Sarjana } \\
\text { Pekerjaan kepala } \\
\text { keluarga }\end{array}$ & $3(3.2)$ & $1(1.1)$ & \\
\hline PNS & $1(1.1)$ & 0 & $\mathrm{~N} / \mathrm{A}$ \\
\hline Pegawai swasta & 0 & $2(2.2)$ & \\
\hline Honorer & $1(1.1)$ & $3(3.3)$ & \\
\hline Wiraswasta & $15(16.0)$ & $24(26.4)$ & \\
\hline $\begin{array}{l}\text { Buruh/ kuli/ } \\
\text { pembantu }\end{array}$ & $11(11.7)$ & $17(18.7)$ & \\
\hline
\end{tabular}

Tabel 2.2. Karakteristik responden

\begin{tabular}{|c|c|c|c|}
\hline \multirow[b]{2}{*}{ Variabel } & \multicolumn{2}{|c|}{ Status Gizi } & \multirow[b]{2}{*}{$p$} \\
\hline & $\begin{array}{l}\text { Stunting } \\
(n=94)\end{array}$ & $\begin{array}{l}\text { Normal } \\
(n=91)\end{array}$ & \\
\hline Lain-lain & 66 (70.2) & $45(49.5)$ & \\
\hline $\begin{array}{l}\text { Penghasilan per } \\
\text { bulan }(R p) \\
\text { mean } \pm S D\end{array}$ & $\begin{array}{c}717375 \pm 144 \\
713\end{array}$ & $\begin{array}{c}1417349 \pm 20 \\
2534\end{array}$ & 0.081 \\
\hline $\begin{array}{l}\text { Jumlah anggota } \\
\text { keluarga, } \\
\text { mean } \pm S D\end{array}$ & $4.78 \pm 1.61$ & $5.07 \pm 1.73$ & 0.240 \\
\hline $\begin{array}{l}\text { Anak hidup, } \\
\text { mean } \pm S D \\
\text { lbu tinggal } \\
\text { dirumah sendiri }\end{array}$ & $2.64 \pm 1.57$ & $2.42 \pm 1.17$ & 0.281 \\
\hline $\begin{array}{l}\text { Ya } \\
\text { Tidak }\end{array}$ & $\begin{array}{l}46(48.9) \\
48(51.1)\end{array}$ & $\begin{array}{l}38(41.8) \\
53(58.2)\end{array}$ & 0.405 \\
\hline $\begin{array}{l}\text { Anggota keluarga } \\
\text { tambahan }\end{array}$ & & & \\
\hline $\begin{array}{l}\text { Ya (keluarga } \\
\text { luas) }\end{array}$ & $20(21.3)$ & 35 (38.5) & $0.017^{*}$ \\
\hline $\begin{array}{l}\text { Tidak (keluarga } \\
\text { inti) }\end{array}$ & 74 (78.7) & $56(61.5)$ & \\
\hline
\end{tabular}

Tabel 1. Diketahui bahwa terdapat hubungan pendidikan dan bentuk keluarga dengan kejadian stunting $(p<0.05)$. Namun tidak terdapat hubungan umur, berat badan lahir, urutan kelahiran anak, pekerjaan kepala keluarga, penghasilan per bulan, jumlah anggota keluarga, anak hidup dan ibu tinggal di rumah sendiri dengan kejadian stunting ( $p>0.05)$. 


\section{Pola Asuh Makan}

Tabel 2. Gambaran pemberian ASI dan MP-ASI

\begin{tabular}{lccc}
\hline \multirow{2}{*}{ Variabel } & \multicolumn{2}{c}{ Status Gizi } & \\
\cline { 2 - 3 } & $\begin{array}{c}\text { Stunting } \\
(\mathbf{n}=94)\end{array}$ & $\begin{array}{c}\text { Normal } \\
(\mathbf{n}=91)\end{array}$ & $\mathbf{p}$ \\
\hline Pemberian ASI & & & \\
$\quad$ Ada & $25(26.6)$ & $25(27.5)$ & 1.000 \\
$\quad$ Tidak & $69(73.4)$ & $66(72.5)$ & \\
Umur diberi ASI saja & $6.02 \pm 2.99$ & $6.33 \pm 3.36$ & 0.510 \\
(bulan), mean \pm SD & & & \\
Hingga saat ini & & & \\
masih diberi ASI & & & \\
$\quad$ Ya & $38(40.4)$ & $38(41.8)$ & 0.972 \\
$\quad$ Tidak & $56(59.6)$ & $53(58.2)$ & \\
$\begin{array}{l}\text { Sudah disapih (tidak } \\
\text { diberi ASI lagi) }\end{array}$ & & & \\
$\quad \begin{array}{l}\text { Ya } \\
\quad \text { Tidak }\end{array}$ & $61(64.9)$ & $55(60.4)$ & 0.635 \\
$\begin{array}{l}\text { Umur disapih } \\
\text { (bulan), mean } \pm S D\end{array}$ & $33(35.1)$ & $36(39.6)$ & \\
\hline
\end{tabular}

Tabel 2. diketahui tidak terdapat hubungan pemberian ASI, umur pemberian ASI saja, pemberian ASI hingga saat ini, sudah dilakukan penyapihan dan umur penyapihan dengan kejadian stunting ( $p>0.05)$.

Gambaran pola asuh makan dapat dilihat pada tabel 3 dan tabel 4 berikut.
Tabel 3. Gambaran pola asuh makan dalam pemberian ASI

\begin{tabular}{|c|c|c|c|}
\hline \multirow[b]{2}{*}{ Variabel } & \multicolumn{2}{|c|}{ Status Gizi } & \multirow[b]{2}{*}{$\mathbf{p}$} \\
\hline & $\begin{array}{l}\text { Stunting } \\
(n=94)\end{array}$ & $\begin{array}{l}\text { Normal } \\
(n=91)\end{array}$ & \\
\hline \multicolumn{4}{|l|}{ Intensitas ASI } \\
\hline Tergantung & $38(69.1)$ & $33(52.4)$ & 0.170 \\
\hline \multicolumn{4}{|l|}{ kebutuhan anak } \\
\hline 7 kali sehari & $10(18.2)$ & $16(25.4)$ & \\
\hline 3 kali sehari & $7(12.7)$ & $14(22.2)$ & \\
\hline $\begin{array}{l}\text { Pemberian } \\
\text { pengganti ASI }\end{array}$ & \multicolumn{2}{|c|}{ pengganti ASI } & \\
\hline Ya & $26(44.8)$ & $27(49.1)$ & 0.791 \\
\hline Tidak & $32(55.2)$ & $28(50.9)$ & \\
\hline \multicolumn{4}{|l|}{ Alasan tidak } \\
\hline ASI tidak keluar & $3(5.2)$ & $1(1.8)$ & 0.712 \\
\hline $\begin{array}{l}\text { Anak muntah bila } \\
\text { menyusui }\end{array}$ & $1(1.7)$ & $1(1.8)$ & \\
\hline Ibu sakit/hamil lagi & $6(10.3)$ & $6(10.9)$ & \\
\hline Ibu sibuk bekerja & $4(6.9)$ & $1(1.8)$ & \\
\hline Anak sudah besar & $37(63.8)$ & $37(67.3)$ & \\
\hline $\begin{array}{l}\text { ASI saja tidak } \\
\text { cukup }\end{array}$ & $3(5.2)$ & $2(3.6)$ & \\
\hline Dan lain-lain & $4(6.9)$ & $7(12.7)$ & \\
\hline Pemberian MP-ASI & $94(100)$ & $91(100)$ & N/A \\
\hline \multicolumn{4}{|l|}{ Nafsu makan } \\
\hline Cukup baik & $59(63.4)$ & $64(70.3)$ & 0.562 \\
\hline Menurun & $29(31.2)$ & $24(26.4)$ & \\
\hline Tidak mau makan & $5(5.4)$ & $3(3.3)$ & \\
\hline \multicolumn{4}{|l|}{$\begin{array}{l}\text { Usaha yang } \\
\text { dilakukan bila anak } \\
\text { tidak nafsu makan }\end{array}$} \\
\hline $\begin{array}{l}\text { Mendorong anak } \\
\text { untuk makan }\end{array}$ & $27(29.0)$ & $38(41.8)$ & 0.243 \\
\hline $\begin{array}{l}\text { Menukar menu } \\
\text { yang disukai anak }\end{array}$ & $40(43.0)$ & $36(39.6)$ & \\
\hline $\begin{array}{l}\text { Memberi } \\
\text { vitamin atau } \\
\text { obat peningkat } \\
\text { nafsu makan }\end{array}$ & $8(8.6)$ & $3(3.3)$ & \\
\hline $\begin{array}{l}\text { Membawa ke } \\
\text { dokter/bidan }\end{array}$ & $3(3.2)$ & $1(1.1)$ & \\
\hline Dan lain-lain & $15(16.1)$ & $13(14.3)$ & \\
\hline
\end{tabular}


Tabel 4.1. Gambaran pola asuh makan pada tindakan pemberian makanan

\begin{tabular}{|c|c|c|c|}
\hline \multirow[b]{2}{*}{ Variabel } & \multicolumn{2}{|c|}{ Status Gizi } & \multirow[b]{2}{*}{$\mathbf{p}$} \\
\hline & $\begin{array}{l}\text { Stunting } \\
(n=94)\end{array}$ & $\begin{array}{l}\text { Normal } \\
(n=91)\end{array}$ & \\
\hline \multicolumn{4}{|l|}{$\begin{array}{l}\text { Anak disuapi saat } \\
\text { makan }\end{array}$} \\
\hline Ya & $62(66.7)$ & $60(65.9)$ & 1.000 \\
\hline Tidak & $31(33.3)$ & $31(34.1)$ & \\
\hline \multicolumn{4}{|l|}{$\begin{array}{l}\text { Tindakan ibu saat } \\
\text { menyuapi } \\
\text { makanan }\end{array}$} \\
\hline $\begin{array}{l}\text { Makan } \\
\text { sambil } \\
\text { bercerita, } \\
\text { bermain dan } \\
\text { bercanda }\end{array}$ & $74(79.6)$ & $73(80.2)$ & 1.000 \\
\hline $\begin{array}{l}\text { Tidak boleh } \\
\text { makan } \\
\text { sambil } \\
\text { bercerita, } \\
\text { bermain dan } \\
\text { bercanda }\end{array}$ & $19(20.4)$ & $18(19.8)$ & \\
\hline $\begin{array}{l}\text { Anak mencoba } \\
\text { makan sendiri } \\
\text { dan diberi }\end{array}$ & & & \\
\hline kesempatan & & & \\
\hline $\mathrm{Ya}$ & $92(98.9)$ & $91(100.0)$ & 1.000 \\
\hline Tidak & $1(1.1)$ & 0 & \\
\hline $\begin{array}{l}\text { Tindakan ibu saat } \\
\text { anak makan } \\
\text { sendiri }\end{array}$ & & & \\
\hline Dibimbing & $81(87.1)$ & 78 (85.7) & 0.953 \\
\hline Dibiarkan & 12 (12.9) & $13(14.3)$ & \\
\hline $\begin{array}{l}\text { Anak susah } \\
\text { makan }\end{array}$ & & & \\
\hline $\mathrm{Ya}$ & $37(39.8)$ & $27(29.7)$ & 0.199 \\
\hline Tidak & $56(60.2)$ & $64(70.3)$ & \\
\hline
\end{tabular}

Tabel 4.2. Gambaran pola asuh makan pada tindakan pemberian makanan

\begin{tabular}{|c|c|c|c|}
\hline \multirow[b]{2}{*}{ Variabel } & \multicolumn{2}{|c|}{ Status Gizi } & \multirow[b]{2}{*}{$\mathbf{p}$} \\
\hline & $\begin{array}{c}\text { Stunting } \\
(n=94)\end{array}$ & $\begin{array}{l}\text { Normal } \\
(n=91)\end{array}$ & \\
\hline \multicolumn{4}{|l|}{$\begin{array}{l}\text { Upaya dilakukan } \\
\text { saat susah makan }\end{array}$} \\
\hline \multicolumn{4}{|l|}{ sambil bermain } \\
\hline Membujuknya & $11(29.7)$ & $11(40.7)$ & \\
\hline $\begin{array}{l}\text { Memaksa anak } \\
\text { makan }\end{array}$ & $2(5.4)$ & $2(7.4)$ & \\
\hline Dibiarkan & $5(13.5)$ & $1(3.7)$ & \\
\hline $\begin{array}{l}\text { Terdapat } \\
\text { makanan } \\
\text { pantangan untuk } \\
\text { anak }\end{array}$ & & & \\
\hline Ada & $10(10.8)$ & $7(7.7)$ & 0.644 \\
\hline Tidak ada & $83(89.2)$ & $84(92.3)$ & \\
\hline \multicolumn{4}{|l|}{$\begin{array}{l}\text { Tindakan ibu saat } \\
\text { anak }\end{array}$} \\
\hline Dipuji & $80(86.0)$ & $84(92.3)$ & $\mathrm{N} / \mathrm{A}$ \\
\hline Dibiarkan & $12(12.9)$ & $7(7.7)$ & \\
\hline Diberi upah & $1(1.1)$ & 0 & \\
\hline \multicolumn{4}{|l|}{ Makan bersama } \\
\hline \multicolumn{4}{|l|}{ keluarga setiap } \\
\hline \multicolumn{4}{|l|}{ hari } \\
\hline Tidak pernah & $6(6.5)$ & $7(7.7)$ & 0.605 \\
\hline Kadang-kadang & $53(57.0)$ & $57(62.6)$ & \\
\hline Selalu & $34(36.6)$ & $27(29.7)$ & \\
\hline \multicolumn{4}{|l|}{$\begin{array}{l}\text { Anak diberikan } \\
\text { makanan jajanan }\end{array}$} \\
\hline $\mathrm{Ya}$ & $91(97.8)$ & $90(98.9)$ & 1.000 \\
\hline Tidak & $2(2.2)$ & $1(1.1)$ & \\
\hline
\end{tabular}

Tabel 3 dan Tabel 4 diketahui tidak terdapat hubungan pola asuh makan dengan kejadian stunting ( $p>0.05)$. 
Tabel 5. Distribusi rerata asupan zat gizi makro dan mikro

\begin{tabular}{|c|c|c|}
\hline \multirow[b]{2}{*}{ Variabel } & \multicolumn{2}{|c|}{ Status Gizi } \\
\hline & $\begin{array}{c}\text { Stunting } \\
(n=94) \\
\text { Mean } \pm S D\end{array}$ & 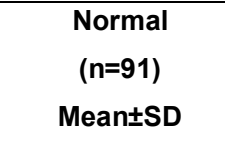 \\
\hline Energi (kkal) & $1016.14 \pm 445.78$ & $1118.28 \pm 601.328$ \\
\hline $\begin{array}{c}\text { Protein } \\
\text { (gr) }\end{array}$ & $45.44 \pm 24.86$ & $50.09 \pm 30.59$ \\
\hline $\begin{array}{l}\text { Lemak } \\
\text { (gr) }\end{array}$ & $36.91 \pm 21.60$ & $42.17 \pm 29.35$ \\
\hline $\begin{array}{l}\text { Karbohidrat } \\
\text { (gr) }\end{array}$ & $127.32 \pm 51.28$ & $136.33 \pm 67.47$ \\
\hline Kalsium (mg) & $399.63 \pm 295.61$ & $458.21 \pm 385.81$ \\
\hline $\begin{array}{l}\text { Fosfor } \\
(\mathrm{mg})\end{array}$ & $767.20 \pm 471.84$ & $869.82 \pm 638.30$ \\
\hline $\begin{array}{c}\text { Vitamin A } \\
(\text { rrq })\end{array}$ & $1349.73 \pm 814.01$ & $1489.61 \pm 993.89$ \\
\hline $\begin{array}{l}\text { Magnesium } \\
\quad(\mathrm{mg})\end{array}$ & $138.03 \pm 82.06$ & $147.45 \pm 95.31$ \\
\hline $\begin{array}{l}\text { Zinc } \\
(\mathrm{mg})\end{array}$ & $4.59 \pm 2.48$ & $4.9199 \pm 2.83$ \\
\hline
\end{tabular}

Tabel 6. Kategori kecukupan asupan zat gizi makro pada responden

\begin{tabular}{|c|c|c|c|}
\hline \multirow[b]{2}{*}{ Variabel } & \multicolumn{2}{|c|}{ Status Gizi } & \multirow[b]{2}{*}{$\mathbf{p}$} \\
\hline & $\begin{array}{l}\text { Stunting } \\
(n=94)\end{array}$ & $\begin{array}{c}\text { Normal } \\
(n=91)\end{array}$ & \\
\hline \multicolumn{4}{|l|}{ Kecukupan } \\
\hline \multicolumn{4}{|l|}{ asupan energi } \\
\hline Kurang & $41(43.6 \%)$ & $34(37.4 \%)$ & 0.559 \\
\hline Cukup & $27(28.7 \%)$ & $26(28.6 \%)$ & \\
\hline Lebih & $26(27.7 \%)$ & $31(34.1 \%)$ & \\
\hline \multicolumn{4}{|l|}{ Kecukupan } \\
\hline \multicolumn{4}{|l|}{ Asupan } \\
\hline \multicolumn{4}{|l|}{ Protein } \\
\hline Kurang & $16(17 \%)$ & $12(13.2 \%)$ & 0.741 \\
\hline Cukup & $11(11.7 \%)$ & $10(11 \%)$ & \\
\hline Lebih & $67(71.3 \%)$ & $69(75.8 \%)$ & \\
\hline \multicolumn{4}{|l|}{ Kecukupan } \\
\hline \multicolumn{4}{|l|}{ Lemak } \\
\hline Kurang & $54(57.4 \%)$ & $44(48.4 \%)$ & 0.434 \\
\hline Cukup & $16(17.0 \%)$ & $17(18.7 \%)$ & \\
\hline Lebih & $24(25.5 \%)$ & $30(33 \%)$ & \\
\hline \multicolumn{4}{|l|}{ Kecukupan } \\
\hline \multicolumn{4}{|l|}{ Karbohidrat } \\
\hline Kurang & $5(5.3 \%)$ & $7(7.7 \%)$ & 0.739 \\
\hline Cukup & $9(9.6 \%)$ & $7(7.7 \%)$ & \\
\hline Lebih & $80(85.1 \%)$ & $77(84.6 \%)$ & \\
\hline
\end{tabular}

Tabel 7. Kategori kecukupan asupan zat gizi mikro pada responden

\begin{tabular}{|c|c|c|c|}
\hline \multirow[b]{2}{*}{ Variabel } & \multicolumn{2}{|c|}{ Status Gizi } & \multirow[b]{2}{*}{ p } \\
\hline & $\begin{array}{c}\text { Stunting } \\
(n=94)\end{array}$ & $\begin{array}{c}\text { Normal } \\
(n=91)\end{array}$ & \\
\hline \multicolumn{4}{|l|}{ Kecukupan } \\
\hline \multicolumn{4}{|l|}{ asupan } \\
\hline \multicolumn{4}{|l|}{ Vitamin A } \\
\hline Kurang & $3(3.2 \%)$ & $4(4.4 \%)$ & 0.351 \\
\hline Cukup & $6(6.4 \%)$ & $2(2.2 \%)$ & \\
\hline Lebih & $85(90.4)$ & $85(93.4 \%)$ & \\
\hline \multicolumn{4}{|l|}{ Kecukupan } \\
\hline \multicolumn{4}{|l|}{ Asupan Zinc } \\
\hline Kurang & $31(33 \%)$ & $27(29.7 \%)$ & 0.730 \\
\hline Cukup & $24(25.5 \%)$ & $21(23.1 \%)$ & \\
\hline Lebih & $39(41.5 \%)$ & $43(47.3 \%)$ & \\
\hline \multicolumn{4}{|l|}{ Kecukupan } \\
\hline \multicolumn{4}{|l|}{ Asupan } \\
\hline \multicolumn{4}{|l|}{ kalsium } \\
\hline Kurang & $74(78.7 \%)$ & $67(73.6 \%)$ & 0.540 \\
\hline Cukup & $10(10.6 \%)$ & $9(9.9 \%)$ & \\
\hline Lebih & $10(10.6 \%)$ & $15(16.5 \%)$ & \\
\hline \multicolumn{4}{|l|}{ Kecukupan } \\
\hline \multicolumn{4}{|l|}{ Asupan } \\
\hline \multicolumn{4}{|l|}{ Magnesium } \\
\hline Kurang & $6(6.4 \%)$ & $10(11 \%)$ & 0.495 \\
\hline Cukup & $7(7.4 \%)$ & $5(5.5 \%)$ & \\
\hline Lebih & $81(86.2 \%)$ & $76(83.5 \%)$ & \\
\hline \multicolumn{4}{|l|}{ Kecukupan } \\
\hline \multicolumn{4}{|l|}{ Asupan Fosfor } \\
\hline Kurang & $22(23.4 \%)$ & $22(24.2 \%)$ & 0.891 \\
\hline Cukup & $14(14.9 \%)$ & $11(12.1 \%)$ & \\
\hline Lebih & $58(61.7 \%)$ & $58(63.7 \%)$ & \\
\hline
\end{tabular}

Pada Tabel 6 dan 7 tidak terdapat hubungan kecukupan asupan zat gizi makro dan mikro dengan kejadian stunting $(p<0,05)$.

\section{PEMBAHASAN}

\section{Karakteristik Responden}

Penelitian ini melibatkan 184 responden yang terdiri dari 94 anak stunting dan 90 anak normal. Dari 184 responden tersebut berjenis kelamin laki-laki $49,73 \%$ dan perempuan $50,27 \%$. Panjang badan lahir normal di Indonesia sekitar $48-52 \mathrm{~cm}$ dan proses terjadinya stunting sudah dimulai di dalam rahim ibu 5 . 
Menurut hasil penelitian ini, anak stunting memiliki panjang badan lebih pendek $5,38 \mathrm{~cm}$ dibandingkan anak normal, namun dari data berat badan lahir tidak ditemukan perbedaan anak normal dan anak stunting.

Data karakteristik responden juga berkaitan dengan pendidikan orang tua. Tingkat pendidikan keluarga anak normal lebih baik dibandingkan dengan keluarga anak stunting. Kepala keluarga anak stunting lebih banyak yang tidak sekolah. Pentingnya tingkat pendidikan orang tua berhubungan dengan daya tangkap dalam menerima informasi tentang gizi dan kesehatan. Kemampuan dalam menerima informasi dapat memudahkan kebutuhan gizi anak tercapai, maka tingkat pendidikan kepala keluarga sangat dibutuhkan demi kesehatan keluarga.

Bentuk keluarga juga berhubungan dengan tumbuh kembang anak. Banyak keluarga anak normal terdapat anggota keluarga tambahan selain keluarga inti dibandingkan dengan anak stunting yang banyak terdiri dari keluarga inti saja. Hubungan antara kedua hal tersebut pada kualitas pengasuhan dan pengawasan gizi yang diperlukan anak dan keluarga. Ketika tidak ada keluarga inti yang mengasuh anak, maka anggota keluarga tambahan dapat menggantikan dalam mengasuh anak ${ }^{6,7}$.

\section{Riwayat Pemberian ASI}

Riwayat pemberian ASI pada anak hampir sama, dimana pada anak stunting sekitar $26,6 \%$ dan anak normal sebesar $27,5 \%$. Sedangkan pemberian ASI eksklusif hampir sama. Umur anak disapih dari menyusi lebih cepat, dimana anak stunting usia 15,7 bulan dan anak normal 16,2 bulan. Pemberian ASI dan ASI eksklusif dan menyapih hampir sama dari kedua kelompok anak ini8,9.

\section{Pola Asuh Makan}

Kebiasaan ibu dalam memberi makan anak sehari-hari, ditemukan sepertiga anak usia 1 - 3 tahun disuruh makan sendiri baik anak stunting maupun anak normal. Sebanyak $39,8 \%$ anak stunting mengalami susah makan, sedangkan anak normal sebesar 29,7. Bila anak tidak mau makan sebagian besar melakukan upaya menyuapi dan membujuk
$80 \%$ pada anak stunting dan $88 \%$ pada anak normal. Dalam memberi makan anak, ibu memberikan jajan bila anak bisa menghabiskan makan. Sebagian besar anak tidak pernah dan tidak selalu makan bersama keluarga.

Jika dilihat gambaran pola asuh makan anak di tempat penelitian terlihat masih belum baik terutama pada anak stunting. Pelaksanaan pola makan yang baik oleh ibu atau pengganti pengasuh merupakan salah satu yang menentukan besarnya intake anak. Pada akhirnya berkaitan dengan status gizi anak ${ }^{7,10}$. Lebih tingginya angka susah makan yang dialami anak stunting dibandingkan anak normal berkaitan dengan intake zat gizi anak yang jika terjadi pada masa golden age maka akan menyebabkan perkembangan otak dan motorik anak terhambat. Perilaku ibu anak stunting untuk membujuk anak jika susah makan kurang daripada perilaku ibu anak normal. Perlunya keaktifan ibu dalam mengasuh anak terutama pada pola asuh makan sangat berkaitan dengan banyaknya zat gizi yang diserap oleh anak.

\section{Intake Zat Gizi}

Hasil penelitian ini menujukkan meskipun tidak terdapat hubungan antara angka kecukupan gizi makro dan mikro terhadap kejadian stunting. Pada tabel 5 terlihat bahwa semua zat gizi makro (energi, protein, lemak, dan karbohidrat) dan mikro (kalsium, fosfor, vitamin A, magnesium, dan zinc) yang diserap lebih rendah pada anak stunting daripada anak normal.

Persentasi anak yang kurang zat gizi makro khususnya asupan energi sebanyak $43,6 \%$ pada anak stunting dan $37,4 \%$ pada anak normal. Untuk zat gizi mikro, sebanyak $78,7 \%$ pada anak stunting dan $73,6 \%$ pada anak normal kekurangan asupan kalsium.

Pada penelitian sebelumnya asupan kalsium signifikan lebih rendah pada anak stunting dibandingkan anak normal ${ }^{11}$. Meskipun tidak menunjukkan signifikansi pada penelitian ini, asupan kalsium anak stunting juga lebih rendah dibandingkan anak normal. Kalsium sangat diperlukan selama pertumbuhan. Apabila asupan kalsium sangat rendah, maka dapat menyebabkan hipoklasemia. Kekurangan kalsium akan mempengaruhi pertumbuhan linier jika 
kandungan kalsium dalam tulang kurang dari 50\% kandungan normal dan pada bayi dapat menyebabkan rakitis, sedangkan pada anak-anak dapat menyebabkan terhambatnya pertumbuhan ${ }^{12}$.

\section{SIMPULAN}

Studi anak stunting dan anak normal pada peneltian ini menunjukkan tidak adanya hubungan antara pola asuh makan dan intake zat gizi anak dengan kejadian stunting di Kabupaten Pasaman dan Pasaman Barat, Sumatera Barat. Pola asuh di tempat penelitian terlihat masih belum baik terutama pada anak stunting dan hal tersebut berkaitan dengan intake zat gizi anak. Zat makro dan mikro makanan lebih sedikit diserap oleh anak stunting dibandingkan anak normal.

\section{UCAPAN TERIMA KASIH}

Terima kasih kepada Kementerian Kesehatan, Departemen Gizi Republik Indonesia yang telah memberikan dukungan dana sehingga penelitian ini dapat diselesaikan dengan baik.

\section{DAFTAR PUSTAKA}

1. Black RE, Victora CG, Walker S.P. Maternal and child undernutrition and overweight in low-income and middle-income countries. Lancet. 2013;382:427-51.

2. Semba RD, Shardell M, Sakr Ashour FA, Moaddel $\mathrm{R}$, Trehan I, Maleta KM, Ordiz MI, Kraemer K, Khadeer MA, Ferrucci $L$, et al. Child stunting is associated with low circulating essential amino acids. EbioMedicine. 2016;6:246-52.

3. UNICEF/World Health Organization/World Bank Group. United Nations Children's Fund, World Health Organization, and World Bank Group. 2015.
Levels and trends in child malnutrition: key findings of the 2015 edition. Tersedia dari: http://www.who.int/nutgrowthdb/jme brochure2015 .pdf?ua=1

4. McGregor SG, Cheung YB, Cueto S, Glewwe P, Richter L, Strupp B, and the International Child Development Steering Group. Developmental potential in the first 5 years for children in developing countries. Lancet. 2007;369(9555):60 70.

5. Kementerian Kesehatan RI. Riset Kesehatan. Jakarta: Kementerian Kesehatan RI; 2010.

6. Jellife DB. Community Nutrional assessment. New York:Oxford University Press; 1989.

7. Masrul. Kajian peranan sumber daya pengasuhan terhadap tumbuh kembang bayi usia $6-12$ bulan pada keluarga etnik Minangkabau di pedesaan provinsi Sumatera Barat [disertasi]. Surabaya: Program Pasca Sarjana Universitas Airlangga; 2005.

8. Soetjimipsil, Ranuh. Strategi kelangsungan hidup anak dalam; tumbuh kembang anak. 1998. hlm.127-40.

9. Henmughan HB, Mc Gregor GG. Pemberian ASI dan pengasuh terhadap tumbuh kembang anak dalam: gizi kesehatan masyarakat. Jakarta: EGC; 2005;300-10.

10. Engle PL, Menon P, Haddad L. care and nutrition: Concepts and Measurement International Food Policy Reseacrh. 1995.

11. Sari EM, Juffrie M, Nuraini N, Sitaresmi MN. Asupan protein, kalsium dan fosfor pada anak stunting dan tidak stunting usia 24-59 bulan. Jurnal Gizi Klinik Indonesia. 2016;12(4):152-9.

12. Peacock M. Calcium metabolism in health and disease. Clin J Am Soc Nephrol. 2010;5(1):23-30. 